\title{
EFFECT OF LACTATION STAGE, ITS NUMBER, CURRENT MILK PERFORMANCE AND BARN AIR TEMPERATURE ON LATERALITY OF HOLSTEIN DAIRY COWS LAYING BEHAVIOUR
}

\author{
P. Zejdová, D. Falta, G. Chládek, L. Máchal
}

Received: April 28, 2011

\begin{abstract}
ZEJDOVÁ, P., FALTA, D., CHLÁDEK, G., MÁCHAL, L.: Effect of lactation stage, its number, current milk performance and barn air temperature on laterality of Holstein dairy cows laying behaviour. Acta univ. agric. et silvic. Mendel. Brun., 2011, LIX, No. 5, pp. 315-322

The aim of this study was to determine effect of lactation stage and number, current milk performance and ambient temperature on laterality of dairy cows laying behaviour (i.e. preference of either left or right body side). The monitoring was performed at the University Training Farm in Žabčice, Czech Republic, (geographical coordinates 49 0'4" N and 16 $36^{\circ}$ E, the altitude $179 \mathrm{~m}$ ) within the six warmest months of the year 2010 (i.e. from 1 April 2010 to 30 September 2010). Observed were altogether 70 Holstein dairy cows with the average daily milk production of $34.48 \mathrm{~kg}$ of milk, which were kept in loose housing boxes with bedding (size of boxes: $2500 \mathrm{~mm}$ x $1250 \mathrm{~mm}$ ). Animals were directly observed once a week (always at 9.00 a.m.). In the course of observation, the position of dairy cows in the barn was exactly recorded. In case of laying animals, it was recorded on which body side they were resting. Altogether 1,239 records of laying position of individual dairy cows were analysed and it was found out that the experimental animals preferred the left body side of their body (left and right laterality was observed in 671 and 568 animals, respectively). This left-side laterality was more frequent among animals in later stages of lactation (more than 200 days) and also in dairy cows with a higher number of lactations ( $4^{\text {th }}$ and more). Dairy cows with a below-average milk performance rested on their left body side more frequently than those with a high level of milk production. As compared with average and/or low air temperatures, the left laterality was more frequent in periods of high ambient temperatures.
\end{abstract}

dairy cow, laterality, stage of lactation, lactation number, temperature of barn atmosphere, milk performance

Nowadays, animal welfare is a topic, which is discussed more and more frequently. When speaking about welfare we can also say that the animal is "happy" and it is generally known that only "happy" animals can reach the maximum level of their performance - of course within the limits of their physiological capacity. For that reason the animal welfare should be in the focus of interest of not only animal protectionists but also animal breeders and herdsmen who should be maximally interested in the welfare of their animals. However, when evaluating the degree/extent of animal welfare, we usually encounter some unexpected problems because it is not possible to asses the level of "satisfaction" by common technical means and/ or methods. To solve this problem, many authors tried to calculate various indexes and formulas and at present one of the most frequent is the so-called cow comfort index (CCI), which expresses the ratio of cows standing to lying in the stall (Nocek, 2009; Ito et al., 2009). When estimating the CCI within an interval of 1 to 2 hours after milking, its value should be higher than $85 \%$ (Stone, 2006). The time cows spend lying down and how often they lie down 
then can be used to evaluate the quality of barns and it should be emphasised in this context that the access to a comfortable lying area is one of the most important design criteria in the field of dairy cow housing (Ito et al., 2009).

From time to time, all animals need to have a rest and to sleep unmolested. To satisfy this need, they require a place that would be comfortable, hygienic and safe. The relative importance of these requirements differs in dependence on the type and age of the animal. For mature dairy cows, the two most important parameters of a good bed are cleanness and excellent plasticity. Good hygiene is very important. Good standard of hygiene is necessary for the reduction of the risk of penetration of microorganisms into the teat canal and the occurrence of mastitis (Webster, 1999). If the bedding layer is thick, the laying period is longer (Colam-Ainsworth et al., 1989; Drissler, et al., 2005). In an experiment performed by Tucker et al. $\left(2009^{b}\right)$ cows spent 3 min more lying down for each additional kilogram of shavings and cows increased lying time by 12 min for every additional kilogram of straw. These results indicated that additional bedding above a scant amount improves cow comfort (as measured by lying time); however, the positive effect of thicker bedding works only to a certain extent because boxes with a too high thick layer of bedding may show a quite opposite effect and prevent a comfortable rest (Doležal et al., 2002).

Important is not only the quality of box surface but also the number of boxes and the free area available for each animal. If the access to free boxes is complicated, the competition among animals becomes more intensive and they must spent more time staying outside boxes so that also the laying period is reduced (Fregonesi et al., 2007). Thus, it could be expected that dairy cows occupying higher position in the herd hierarchy would get an advantage over others when competing for the place of resting and that they would spent more time by laying than the submissive animals. This expectation was corroborated by Rosecká and Štolc (2003) who observed that dairy cows occupying lower positions in the herd hierarchy spent less time by laying than their superior herdmates and that also their milk performance was below the average of the experimental group. Webster (1999), as well, concluded that even in the herd of hornless dairy cow submissive individuals may be harassed/oppressed by others that they do not dare to lay down; they are tired, get thin, their milk performance is reduced and sometimes they even can suffer from leg disorders. On the other hand, however, Lauwere et al. (1996) stated that the daily total times spent lying or feeding were not related to the dominance value.

Time spent for laying is influenced also by the season. Cows spent more time lying during the winter period, regardless to the technology of housing (O'Driscoll et al., 2009).
Besides the lost possibility of comfortable laying and resting, high ambient temperatures and exposition to sun radiation without a possibility to stay in shade in summer represent also very stressing factors for dairy cows. Schutz et al. (2008) described an interesting experiment of this type as follows:

"A group of twelve dairy cows was not allowed to lay and rest for a period of 12 hours. Thereafter, animals were admitted to the pen, in which they could enter either a shaded area (but without possibility to lay and rest) or an area exposed to the sun radiation and enabling comfortable laying. This experiment demonstrated that the time interval spent in shade lengthened in dependence on increasing air temperature. The intensification of solar radiation had a similar effect. This observation indicates that in spite of the fact that for dairy cows it is important to have an opportunity to lie down comfortably, they prefer the possibility to eliminate the heat stress because they preferred staying in the shade to laying in the sun - even after a 12-hour period of forced staying."

Lying comfortably is an essential part of each productive cow's day. The most important of cow's daily needs is the need to lie down and ruminate for 12 to 14 hours a day. Cows that lie for this period are healthier and more productive, while uncomfortable animals lie less and stand more (Thorne, 2008). That is why a number of studies dealing with problems associated with lying of dairy cows were performed. However, they were mostly focused on effects of litter and its quality, housing, and/or ambient temperature. With the laterality and its possible correlations (e.g. age of animals, stage of lactation and/or milk performance, however, dealt only a few of them.

The aim of this experiment was to test effects of stage and number of lactation, current milk performance and ambient temperature on the laterality of laying dairy cows. It was expected that females in higher stages of lactation would prefer left body side when laying and resting (because of enlarged uterus, which is situated to the right in the pelvic cavity). Further it was also expected that laterality of laying and resting would not be influenced by the number of lactation as this parameter was not considered to be important. According to the third of our hypotheses, dairy cows with a lower milk performance would lay on their right side less frequently than the high performing animals (because these should consume more feed so that their rumen contained more digested feed). Finally, the fourth hypothesis expected that at high ambient temperatures, the dairy cows would lay on the left body side more frequently than during the periods of low temperatures, mainly due to a limited feed intake resulting from heat stress so that the volume of their rumen would also be smaller. 


\section{MATERIALS AND METHODS}

The observation of animals took place on the University Training Farm in Žabčice (Czech Republic; geographic coordinates 49 $0^{\circ} 4$ "N and $16^{\circ} 36^{\prime} \mathrm{E}$; altitude $179 \mathrm{~m}$ ) within the period of the six warmest months of the year 2010 (i.e. from 1 April 2010 to 30 September 2010). The experimental barn was the same as that used by Walterová et al. (2009) in their study.

The study object was a barn with loose housing and bedded laying boxes. This barn was longitudinally separated by a feeding table into two parts and each of them was further divided into two sections of the same size so that there were altogether four sections in this barn. In each section, there were 77 comfort laying boxes arranged in three rows with two drinking bowls. Straw was used as the bedding material. Bedding of laying boxes, removal of manure, and supply of roughage were mechanised. Dairy cows leave the barn only for milking, which takes place twice a day (in the morning and in the evening) in the neighbouring milking parlour. The barn is a rectangle and its long walls are fitted with roller curtains, which are pulled down only in case of and extremely raw weather; this means that the long walls are opened for most of the days during the year. Similarly, both gates in shorter front walls are also opened to enable the entry of machinery. The barn is covered with a saddle roof fitted with transparent panels and ventilation slots in the ridge of the roof.

In this experiment, only one section of the barn with Holstein dairy cows was monitored. The average number of animals was 70 (61-92) and they were in different stages of lactation (30 days and more) and also the number of their lactation was different (i.e. from the $1^{\text {st }}$ to the $8^{\text {th }}$ ). None of the females was in the dry period. The average daily milk production per cow was $34.48 \mathrm{~kg}$ of milk.

Experimental animals were directly observed once a week (at the same day in the week), always at 9 a.m. During the observation, the cow's position within the barn and its activity (staying, laying, feed intake) were recorded. In case of laying animals, the laterality (left - right) was recorded as well.

The current milk performance was recorded during each milking, i.e. twice a day. In each month, the average milk production of the experimental group was calculated and the result was used as a base for the division of animals into three performance categories (i.e. Low, Average and High) - see Tab. I.

The ambient temperature was monitored with three HOBO sensors, which were distributed inside the barn at the level of standing animals (i.e. approximately in their shoulder height). In this way it was possible to eliminate the effect of only one place of measuring. The sensors usually recorded the temperature in time intervals of 15 minutes but for the purpose of this experiment only the measuring at 9 a. m. was selected. The arithmetic mean was calculated on the base of these three measured temperatures measured in different parts of the barn section and the results of individual observations were divided into the following three groups: Cold $\left(<15^{\circ} \mathrm{C}\right)$, Average $\left(15-19.9^{\circ} \mathrm{C}\right)$ and Warm $\left(>20^{\circ} \mathrm{C}\right)$. Statistical analysis was performed using the single sample Chi-square test in the programme UNISTAT 5.1.

\section{RESULTS}

\section{Effect of the stage of lactation on laterality}

For purposes of this experiment, the herd was divided into three groups - Group 1 (30-100 days

I: Categorization of cows according to average daily milk yield ( $k g$ )

\begin{tabular}{lcccccc}
\hline & April & May & June & July & August & September \\
\hline Low & $<29$ & $<31$ & $<33$ & $<31$ & $<31$ & $<30$ \\
Average & $29-35$ & $31-37$ & $33-39$ & $31-37$ & $31-36$ & $30-35$ \\
High & $>35$ & $>37$ & $>39$ & $>37$ & $>36$ & $>35$ \\
\hline
\end{tabular}

II: Distribution of animals into groups according to the stage of lactation (numbers of laying dairy cows)

\begin{tabular}{|c|c|c|c|c|c|c|c|c|}
\hline \multicolumn{2}{|c|}{ Group under study } & April & May & June & July & August & September & Total \\
\hline \multirow{2}{*}{$\begin{array}{l}\text { Group } 1 \\
\text { (<100 days } \\
\text { of lactation) }\end{array}$} & Left & $20^{\text {N.S. }}$ & $17^{\text {N.S. }}$ & $37^{\text {N.S. }}$ & $28^{\text {N.S. }}$ & $41^{\text {N.S. }}$ & $40^{\text {N.S. }}$ & $183^{\text {N.S. }}$ \\
\hline & Right & $24^{\text {N.S. }}$ & $18^{\text {N.S. }}$ & $42^{\text {N.s. }}$ & $16^{\text {N.S. }}$ & $27^{\text {N.S. }}$ & $25^{\text {N.S. }}$ & $152^{\text {N.S. }}$ \\
\hline \multirow{2}{*}{$\begin{array}{l}\text { Group } 2 \\
\text { (101-200 days } \\
\text { of lactation) }\end{array}$} & Left & $37^{\text {N.S. }}$ & $35^{\text {N.S. }}$ & $72^{\text {N.S. }}$ & $36^{\text {N.S. }}$ & $35^{\text {N.S. }}$ & $44^{\text {N.S. }}$ & $259^{\text {N.S. }}$ \\
\hline & Right & $46^{\text {N.S. }}$ & $33^{\text {N.s. }}$ & $79^{\text {N.s. }}$ & $29^{\text {N.S. }}$ & $26^{\text {N.S. }}$ & $35^{\text {N.S. }}$ & $248^{\text {N.S. }}$ \\
\hline $\begin{array}{l}\text { Group } 3 \\
\text { (> 201 days } \\
\text { of lactation) }\end{array}$ & Right & $22^{a}$ & $31^{\text {N.S. }}$ & $53^{\text {N.S. }}$ & $24^{\text {N.S. }}$ & $20^{\text {N.s. }}$ & $18^{\text {N.S. }}$ & $168^{\mathrm{A}}$ \\
\hline
\end{tabular}

N.S. - Statistically non-significant $(P>0.05)$ - within the framework of the group under study a, a - Statistically significant $(\mathrm{P} \leq 0.05)$ - within the framework of the group under study A, A - Statistically highly significant $(\mathrm{P} \leq 0.01)$ - within the framework of the group under study 
of lactation), Group 2 (101-200 days of lactation), and Group 3 (201 and more days of lactation). The obtained results indicate that cows in all groups preferred left body side when laying (Tab. II). In individual experimental groups the percentages of laterality (left $v$ s. right side) were as follows: $54.63 \%$ vs. 45.37\% (Group 1), 51.08\% vs. 48.92\% (Group 2), and $59.30 \%$ vs. $40.70 \%$ (Group 3). However, this difference was statistically significant only in Group 3 (P $\leq 0.01$ ). The tested hypothesis was corroborated.

\section{Effect of the number of lactation on laterality}

Also in this case, the animals were divided into three categories: Group 4 (2 $2^{\text {nd }}$ lactation); Group 5 $\left(^{\text {rd }}\right.$ lactation) and Group 6 ( $4^{\text {th }}-8^{\text {th }}$ lactation). Results are presented in Tab. III. Also in this case cows in all three categories preferred to lay and rest on the left body side. In percentages (left $v s$. right side), the results were as follows: Group $454.15 \%$ vs. $45.85 \%$;
Group 5 53.75\% vs. 46.25\% and Group 6 59.49\% vs. $40.51 \%$. A statistically significant difference $(\mathrm{P} \leq 0.01)$ was found out only in Group $6\left(4^{\text {th }}+\right.$ lactation $)$. The hypothesis that the number of lactation would show an effect on the laterality was rejected.

\section{Effect of the current milk performance on laterality}

Dairy cows were divided into three categories according to their milk performance recorded in individual months of monitoring (low, average, high). Also in this case the left body side was preferred when laying (Tab. IV). Individual percentages (left vs. right side) were as follows: Group 7-57.56\% vs. 42.44\%; Group 8-55.76\% vs. $44.24 \%$, and Group $9-54.17 \%$ vs. $45.83 \%$. In dairy cows with low, average and high milk performance, the preference was statistically highly significant $(\mathrm{P} \leq 0.01)$, significant $(\mathrm{P} \leq 0.05)$, and non-

III: Distribution of animals into groups according to the number of lactation (numbers of laying dairy cows)

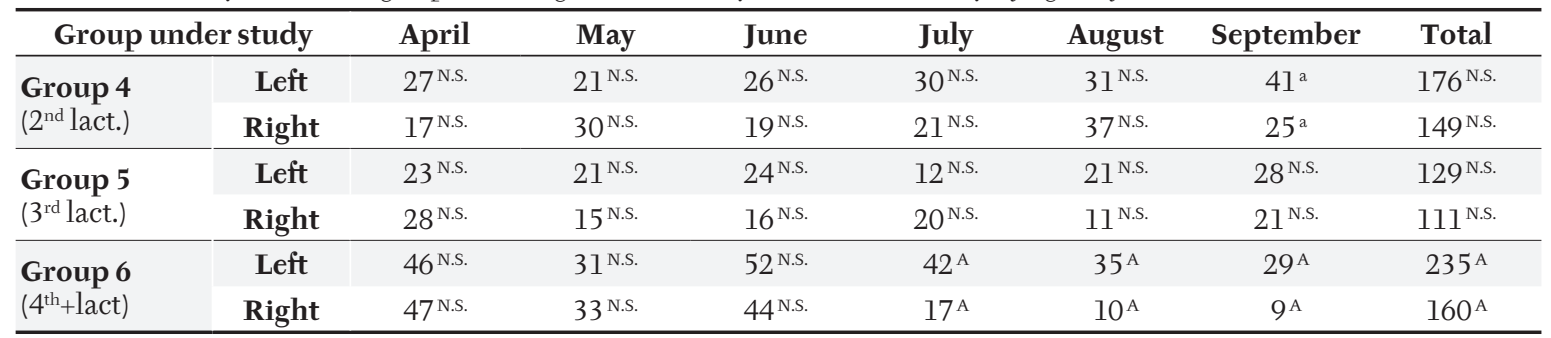

N.S. - Statistically non-significant $(\mathrm{P}>0.05)$ - within the framework of the group under study

a, a - Statistically significant $(P \leq 0.05)$ - within the framework of the group under study

A, A - Statistically highly significant $(\mathrm{P} \leq 0.01)$ - within the framework of the group under study

IV: Distribution of animals into groups according to the milk performance (numbers of laying dairy cows)

\begin{tabular}{|c|c|c|c|c|c|c|c|c|}
\hline \multicolumn{2}{|c|}{ Group under study } & $\frac{\text { April }}{31^{\text {N.S. }}}$ & $\frac{\text { May }}{16^{\text {N.s. }}}$ & $\frac{\text { June }}{31^{\text {N.S. }}}$ & $\frac{\text { July }}{33^{\text {N.S. }}}$ & $\frac{\text { August }}{30^{\text {N.s. }}}$ & $\frac{\text { September }}{38^{\mathrm{a}}}$ & $\frac{\text { Total }}{179^{\mathrm{A}}}$ \\
\hline (Low) & Right & $20^{\text {N.s. }}$ & $16^{\text {N.s. }}$ & $28^{\text {N.S. }}$ & $29^{\text {N.S. }}$ & $20^{\text {N.S. }}$ & $19^{a}$ & $132^{\mathrm{A}}$ \\
\hline \multirow{2}{*}{$\begin{array}{l}\text { Group } 8 \\
\text { (Average) }\end{array}$} & Left & $33^{\text {N.S. }}$ & $30^{\text {N.S. }}$ & $50^{\text {N.s. }}$ & $47^{a}$ & $39^{\text {N.S. }}$ & $38^{\text {N.S. }}$ & $237^{a}$ \\
\hline & Right & $27^{\text {N.S. }}$ & $37^{\text {N.S. }}$ & $42^{\text {N.S. }}$ & $27^{\mathrm{a}}$ & $29^{\text {N.S. }}$ & $26^{\text {N.S. }}$ & $188^{a}$ \\
\hline & Left & $28^{a}$ & $32^{\text {N.S. }}$ & $41^{\text {N.S. }}$ & $22^{\text {N.S. }}$ & $38^{\text {N.S. }}$ & $47^{\text {N.S. }}$ & $208^{\text {N.S. }}$ \\
\hline
\end{tabular}

N.S. - Statistically non-significant $(\mathrm{P}>0.05)$ - within the framework of the group under study

a, a - Statistically significant $(\mathrm{P} \leq 0.05)$ - within the framework of the group under study

A, A - Statistically highly significant $(\mathrm{P} \leq 0.01)$ - within the framework of the group under study

V: Distribution of animals into groups according to the temperature of barn atmosphere (numbers of laying dairy cows)

\begin{tabular}{|c|c|c|c|c|c|c|c|c|}
\hline \multicolumn{2}{|c|}{ Group under study } & $\frac{\text { April }}{96^{\text {N.s. }}}$ & $\frac{\text { May }}{47^{\text {N.s. }}}$ & $\frac{\text { June }}{26^{\text {N.s. }}}$ & $\begin{array}{c}\text { July } \\
0\end{array}$ & $\frac{\text { August }}{18^{\text {N.S. }}}$ & $\frac{\text { September }}{87^{\mathrm{a}}}$ & $\frac{\text { Total }}{274^{a}}$ \\
\hline (Cold) & Right & $92^{\text {N.S. }}$ & $40^{\text {N.S. }}$ & $17^{\text {N.S. }}$ & 0 & $13^{\text {N.S. }}$ & $61^{\mathrm{a}}$ & $223^{a}$ \\
\hline (Average) & Right & 0 & $42^{\text {N.S. }}$ & $45^{\text {N.S. }}$ & $14^{\mathrm{a}}$ & $12^{\mathrm{a}}$ & $16^{\mathrm{A}}$ & $129^{a}$ \\
\hline Group 12 & Left & 0 & 0 & $47^{a}$ & $74^{\text {N.S. }}$ & $61^{\text {N.S. }}$ & 0 & $182^{\mathrm{A}}$ \\
\hline
\end{tabular}

N.S. - Statistically non-significant $(\mathrm{P}>0.05)$ - within the framework of the group under study

a, a - Statistically significant $(\mathrm{P} \leq 0.05)$ - within the framework of the group under study

A, A - Statistically highly significant $(\mathrm{P} \leq 0.01)$ - within the framework of the group under study 
significant, respectively. The tested hypothesis was corroborated.

\section{Effect of the ambient temperature on laterality}

Individual measurements were divided into three groups according to average ambient temperature at the moment of observation (cold, average, warm). The obtained results indicated that the left-side laterality was significant in all three experimental groups, i.e. in all ambient temperatures (Tab. V). The percentages of laterality (left $v$ s. right side) were as follows: Group 10-55.13\% vs. 44.87\%; Group $11-56.57 \%$ vs. $43.43 \%$ and Group $12-58.15 \%$ vs. 41.85\%. In Groups 10 and 11 (Cold and Average) the difference was significant $(\mathrm{P} \leq 0.05)$ and in Group 12 (Warm) statistically highly significant $(P \leq 0.01)$. The tested hypothesis was also corroborated.

\section{DISCUSSION}

According to Gustafson and Lund-Magnussen (1995), the cows of both groups had a side for lying which they significantly preferred. This observation was confirmed also in our experiments. However, these authors also mentioned that for individual cows it could be either the left or the right side. In our experiment, the preference of the left body side was manifested in all groups under study. Hrouz et al. (2007) found out that $53-70 \%$ of observed dairy cows preferred to lay and rest on the left body side. Also Tucker et al. (2009a) wrote that in their experiment with loose housing, dry dairy cows showed left-side laterality. In contradistinction to our results, however, the above authors mentioned that other animals (also in loose housing and/or on pasture) did not show any laterality preference when laying and resting. Forsberg et al. (2008), as well, mentioned in their paper that the cows (of the Swedish Red and White breed) kept in a loose house system with automatic milking chose left and right laterality equally.

In the first experimental variant, in which the effect of the stage of lactation on laterality of laying was evaluated, it was demonstrated that dairy cows in a later stage of lactation preferred left body side more frequently than those in earlier. This corresponded with data published by Forsberg et al. (2008), who reported that in a study performed out on pasture at gestation month 9 , the frequency of observations of cows lying on the left body side was significantly higher $(\mathrm{P}<0.012)$, than those lying on the right side.

In the second variant of our experiments (i.e. effect of lactation number on laterality), the existence of differences among dairy cows of different age and on different lactations. In spite of this, however, it emerged that older animals, i.e. on the $4^{\text {th }}$ and higher lactations, preferred the left body side more frequently than young ones (on the $2^{\text {nd }}$ and the $3^{\text {rd }}$ lactation). This observation differed from findings made by Forsberg et al. (2008), who wrote that there was no effect of age was seen on the choice of lying side.

Laterality of laying is probably not influenced by the degree of rumen repletion because, as mentioned by Tucker et al. (2009) that eating behaviour had only a little effect on time spent lying on either side. It is therefore probable that the preference of left body side, which was observed in our study in the group of low-performance animals, was not correlated with their reduced feed consumption. However, this can be associated with the number of lactation because animals of $4^{\text {th }}+$ lactations significantly preferred laying and resting on the left body side.

In our experiments, the left-side laterality was more marked in periods of higher air temperatures. This could be also correlated with the daytime because the ambient temperatures fluctuated during the day. Wagnon and Rolins (1972) even mentioned that dairy cows preferred to lay and rest on the left body side in the second half of the day $(56 \%$ vs. $50 \%$ in the afternoon and in the morning, respectively). These authors explained this observation on the base of a greater volume if rumen is after the afternoon feeding. This conclusion was, however, in a direct contrast with the aforementioned results published by Tucker et al. (2009a). Regarding the fact that our observations were performed always in the same hour there is no doubt that the effect of daytime can be excluded. This means that an increased preference of the left body side in periods of higher ambient temperatures may be influence by changed eating behaviour under conditions of heat stress (or, possibly, also with some other factors, which should be explained in further studies).

In this experiment the laying position of animals was recorded on in the time of observation and for that reason we did not pay attention to alternatives in laying down. Nevertheless, it seemed that the laterality was influenced by the previous behaviour: animals changed sides of laying and resting more frequently if the preceding laying period was long and/or if it finished only recently. On deep litter, dairy cows alternated body sides more frequently; this was probably caused by the fact that they had a higher number of laying periods with shorter intervals of other activities between them. A long, continuous lying period may become uncomfortable when bouts are longer than 80 minutes so that the cows may switch the body sides to alleviate this discomfort (Tucker et al., 2009a).

\section{CONCLUSION}

When laying down to rest, dairy cows preferred the left body side. This left-side laterality was more obvious in animals with a higher stage of lactation and on higher lactations (more than 200 days and $4^{\text {th }}+$, respectively). Dairy cows with current milk performance lower that the herd average were laying and resting on the left body side more frequently than those with a high milk 
performance. In comparison with average and/or low air temperatures, increased left-side laterality was observed also during periods of high ones.

As shown in this experiment, in dairy cows the laterality is influenced by many factors and for that reason this problem requires further research. The obtained results may be applied partly when designing the interior of barns and cowsheds and partly when trying to increase the comfort of animals because it shows a significant effect on the performance. Last but not least, it is necessary to know the natural patterns of comfort and resting behaviour when evaluating the welfare and health condition of cattle because only those herdsmen who know well needs and requirements of their animals can satisfy them in a due manner.

\section{SUMMARY}

The aim of this study was to determine effect of lactation stage and number, current milk performance and ambient temperature on laterality of dairy cows laying behaviour (i.e. preference of either left or right body side). The monitoring was performed at the University Training Farm in Žabčice, Czech Republic, (geographical coordinates 49 0'4" N and 16 $36^{\prime}$ E, the altitude $179 \mathrm{~m}$ ) within the six warmest months of the year 2010 (i.e. from 1 April 2010 to 30 September 2010). Observed were altogether 70 Holstein dairy cows with the average daily milk production of $34.48 \mathrm{~kg}$ of milk, which were kept in loose housing boxes with bedding (size of boxes: $2500 \mathrm{~mm}$ x $1250 \mathrm{~mm}$ ). Animals were directly observed once a week (always at 9.00 a.m.). In the course of observation, the position of dairy cows in the barn was exactly recorded. In case of laying animals, it was recorded on which body side they were resting.

The research work took place in four experiments. For purposes of $1^{\text {st }}$ experiment, the herd was divided into three groups - Group 1 (30-100 days of lactation), Group 2 (101-200 days of lactation), and Group 3 (201 and more days of lactation). The obtained results indicate that cows in all groups preferred left body side when laying. However, this difference was statistically significant only in Group 3 (P $\leq 0.01)$. Also in the $2^{\text {nd }}$ experiment, the animals were divided into three categories: Group 4 ( $2^{\text {nd }}$ lactation); Group 5 ( $3^{\text {rd }}$ lactation) and Group $6\left(4^{\text {th }}-8^{\text {th }}\right.$ lactation$)$. Also in this case cows in all three categories preferred to lay and rest on the left body side, but statistically significant difference $(\mathrm{P} \leq 0.01)$ was found out only in Group 6. In the $3^{\text {rd }}$ experiment, dairy cows were divided into three categories according to their milk performance recorded in individual months of monitoring (low, average, high). Also in this case the left body side was preferred when laying. In dairy cows with low, average and high milk performance, the preference was statistically highly significant $(P \leq 0.01)$, significant $(\mathrm{P} \leq 0.05)$, and non-significant, respectively. In the last experiment, individual measurements were divided into three groups according to average ambient temperature at the moment of observation (cold, average, warm). The obtained results indicated that the left-side laterality was significant in all three experimental groups. In Groups Cold and Average the difference was significant $(\mathrm{P} \leq 0.05)$ and in Group Warm statistically highly significant $(\mathrm{P} \leq 0.01)$.

\section{Acknowledgements}

This research was supported by grant project AF MENDELU, TP 8/2011 and with support of research programme No. MSM6215648905 "Biological and technological aspects of sustainability of controlled ecosystems and their adaptability to climate" chase from Ministry of education, youth and sports of Czech Republic.

\section{REFERENCES}

COLAM-AINSWORTH, P., LUNN, G. A.; THOMAS, R. C.; EDDY, R. G., 1989: Behaviour of cows in cubicles and its possible relationship with laminitis in replacement dairy heifers. The Veterinary Record, Vol. 125, Issue 23: 573-575, ISSN 0042-4900.

DOLEŽAL, O., BÍLEK, M., ČERNÁ, D., DOLEJŠ, J., GREGORIADESOVÁ, J., KNİŽKOVÁ, I., KUDRNA, V., KUNC, P., TOUFAR, O., 2002: The comfortable accommodation of highyield dairy cows. In Czech: Komfortní ustájení vysokoprodukčních dojnic. Vybrané statě z technologie a techniky chovu hospodářských zvírat. Výzkumný ústav živočišné výroby v Uhříněvsi. Praha. 129 s., ISBN 80-86454-23-1.

DRISSLER, M., GAWORSKI, M., TUCKER, C. B., WEARY, D. M., 2005: Freestall maintenance: Effects on lying behavior of dairy cattle. Journal of dairy science, 88 (7): 2381-2387, ISSN 0022-0302.

FORSBERG, A. M., PETTERSON, G., LJUNGBERG, T., SVENNERSTEN-SJAUNJA, K., 2008: A brief note about cow lying behaviour - Do cows choose left and right side equally? Applied animal behaviour science, 114 (2008): 32-36, ISSN 01641591. 
FREGONESI, J. A., TUCKER, C. B., WEARY, D. M., 2007: Overstocking reduces lying time in dairy cows. Journal of dairy science, 90 (7): 3349-3354, ISSN 0022-0302.

GUSTAFSON, G. M., LUND-MAGNUSSEN, E., 1995: Effect of daily exercise on the getting up and lying down behaviour of tied dairy cows. Preventive veterinary medicine, 25 (1): 27-36, ISSN 0167-5877.

HROUZ, J., MÁCHA, J., KLECKER, D., VESELÝ, P., 2007: Etologie hospodářských zvírat. Mendelova zemědělská a lesnická univerzita $\mathrm{v}$ Brně, 185 s., ISBN 978-80-7157-463-7.

ITO, K., WEARY, D. M., VON KEYSERLINGK, M. A. G., 2009: Lying behavior: Assessing within- and between-herd variation in free-stall-housed dairy cows. Journal of dairy science, 92 (9): 4412-4420, ISSN 0022-0302.

LAUWERE, C. C. K.-d., DEVIR, S., METZ, J. H. M., 1996: The influence of social hierarchy on the time budget of cows and their visits to an automatic milking system. Aplied animal behaviour science, 49 (2): 199-211, ISSN 0168-1591.

NOCEK, J., E., 2009: Cow comfort is a critical component in the development of oxidative stress. Novus Dairy Balance. Available from: http:// www.dairybalance.com/WhattheExpertsSay/ CowComfort.aspx.

O'DRISCOLL, K., BOYLE, L., HANLON, A., 2009: The effect of breed and housing system on dairy cow feeding and lying behaviour. Applied animal behaviour science, 116 (2-4): 156-162, ISSN 01681591.

ROSECKÁ, D., ŠTOLC, L., 2003: Etologie skotu. Zemědělský týdeník (23/2003): 12-13, ISSN 12122246.
SCHUTZ,K.E., COX, N.R., MATTHEWS, L.R., 2008: How important is shade to dairy cattle? Choice between shade or lying following different levels of lying deprivation. Applied animal behaviour science, 114 (3-4): 307-318, ISSN 0168-1591.

STONE, B., 2006: Score seven areas of cow comfort on your dairy. Then put a plan in place to improve areas that get low cow-comfort scores. Northeast Dairy Business Magazine The manager.

THORNE, M., 2008: Busy cows need comfort when they take a rest. Farmers weekly (10/2008). ISSN 0014-8474.

TUCKER, C. B., COX, N. R., WEARY, D. M., SPINKA, M., 2009a: Laterality of lying behaviour in dairy cattle. Applied animal behaviour science, 120 (34): 125-131, ISSN 0164-1591.

TUCKER, C. B., WEARY, D. M., VON KEYSERLINGK, M. A. G., BEAUCHEMIN, K. A., 2009': Cow comfort in tie-stalls: Increased depth of shavings or straw bedding increases lying time. Journal of dairy science, 92 (6): 2684-2690, ISSN 0022-0302.

WAGNON, K. A., ROLLINS, W. C., 1972: Bovine laterality. Journal of animal science, 35: 486-488, ISSN 0021-8812.

WALTEROVÁ, L., ŠAROVSKÁ, L., FALTA, D., CHLÁDEK, G., 2009: Vztah mezi vybranými klimatickými prvky uvnitř a vně stáje dojnic $\mathrm{v}$ průběhu roku. Acta Universitatis Agriculturae et Silviculturae Mendeliande Brunensis (4) 2009: 125132, ISSN 1211-8516.

WEBSTER, J., 1999: Animal welfare: A cool eye towards eden. Blackwell Science Ltd., 264 s., ISBN 80-238-4086.

Ing. Petra Zejdová, Ing. Daniel Falta, PhD., prof. Ing. Gustav Chládek, CSc., prof. Ing. Ladislav Máchal, DrSc., Ústav chovu a šlechtění zvíriat, Mendelova univerzita v Brně, Zemědělská 1, 61300 Brno, Česká republika, e-mail: PetraZejdova@seznam.cz 
